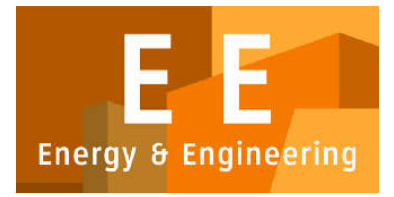

PAPER - OPEN ACCESS

\title{
Studi Penentuan Tempat Pembuangan Akhir Sampah di Kota Tebing Tinggi dengan Metode Proses Hirarki Analitik
}

\author{
Author : Suliawati, dkk \\ DOI $\quad: 10.32734 /$ ee.v2i3.775 \\ Electronic ISSN $\quad: 2654-704 X$ \\ Print ISSN : $2654-7031$
}

Volume 2 Issue 3 - 2019 TALENTA Conference Series: Energy \& Engineering (EE)

This work is licensed under a Creative Commons Attribution-NoDerivatives 4.0 International License.

Published under licence by TALENTA Publisher, Universitas Sumatera Utara 


\section{jidi (1) \\ TALENTA Conference Series}

$P U B L I S H E R$

Available online at https://talentaconfseries.usu.ac.id

\title{
Studi Penentuan Tempat Pembuangan Akhir Sampah di Kota Tebing Tinggi dengan Metode Proses Hirarki Analitik
}

\author{
Suliawati, Mahrani Arfah, Indah Yunita Harbi \\ Fakultas Teknik Universitas Islam Sumatera Utara \\ mahrani.arfah@ft.uisu.ac.id, suliawati@ft.uisu.ac.id, indahyunitaharbi@gmail.com
}

\begin{abstract}
Abstrak
Penelitian ini dilakukan pada sebuah instansi Dinas Perumahan, Kawasan Permukiman, dan Kebersihan Kota Tebing Tinggi, dengan melakukan evaluasi terhadap faktor penentu TPA dengan tujuan mendapatkan penentuan TPA baru Kota Tebing Tinggi. Proses penentuan TPA baru ini dilakukan dengan menggunakan pendekatan metode Analytical Hierarchy Process (AHP). Berdasarkan pengolahan data dengan menggunakan metode tersebut dihasilkan 3 kriteria utama, yaitu kriteria teknis, lingkungan dan sosial, aksebilitas dengan mendapatkan kriteria teknis sebagai kriteria dengan bobot penilaian sebesar 0,4080 (40,8\%). Sedangkan hasil alternatif menempatkan alternatif satu (pengembangan TPST (Tempat Pemrosesan Sampah Terpadu)) sebagai alternatif terbaik dengan bobot penilaian 0,5529 (55,29\%). Dengan dibuatnya suatu model evaluasi penentuan TPA ini diharapkan dapat berguna untuk proses evaluasi lainnya.
\end{abstract}

Kata kunci: Tempat Pembuangan Akhir, sampah, terpadu, AHP

\begin{abstract}
Abstrak
This research was conducted at an agency of Housing, Settlement, and Cleanliness Agency of Tebing Tinggi City, by evaluating the determinants of the TPA with the aim of obtaining a new TPA of Tebing Tinggi City. The process of determining the new TPA is carried out using the Analytical Hierarchy Process (AHP) approach. Based on data processing using these methods produced 3 main criteria, namely technical, environmental and social criteria, accessibility by getting technical criteria as criteria with an assessment weight of 0.4080 (40.8\%). While the alternative results put alternative one (development of TPST (Integrated Waste Processing Sites)) as the best alternative with an assessment weight of 0.5529 (55.29\%). By making an evaluation model for TPA determination, it is expected to be useful for other evaluation processes.
\end{abstract}

Keywords: Final disposal site, solid waste, integrated, AHP

\section{Pendahuluan}

Sampah merupakan masalah yang perlu mendapatkan perhatian serius, terutama bagi masyarakat yang tinggal di kota. Adanya tingkat pertumbuhan kota yang cukup pesat dan beragam aktivitas, penduduknya selalu meninggalkan sisa yang dianggap sudah tidak berguna lagi yaitu sampah dan limbah. Sampah merupakan buangan berupa padat yang merupakan polutan umum yang dapat menyebabkan turunnya nilai estetika lingkungan, membawa berbagai jenis penyakit, menurunkan sumber daya alam, menimbulkan polusi, menyumbat saluran air dan berbagai akibat negatif lainnya.

Tempat Pembuangan Akhir (TPA) sampah merupakan salah satu komponen akhir dalam pengelolaan persampahan. Keberadaan TPA saat ini seringkali menjadi permasalahan baik ditinjau dari komponen daya dukung lingkungan, sosial, budaya dan ekonomi. Komponen-komponen tersebut kerap kali menjadi hambatan dalam pengadaan sarana 
TPA ini dan seringkali menjadi suatu permasalahan yang besar dalam suatu daerah terlebih pada daerah perkotaan dimana lahan untuk TPA dirasakan sudah tidak dialokasikan dalam rencana tata ruangnya.

TPA secara terbuka (open dumping) merupakan tempat pembuangan yang umum dilakukan di kota-kota di Indonesia, salah satunya di Kota Tebing Tinggi. Sampah perkotaan umumnya berupa limbah padat domestik yang dikeluarkan per rumah tangga. Jumlah timbunan sampah yang terlalu banyak yang dihasilkan Kota Tebing Tinggi menyebabkan ketersediaan lahan sangat penting dalam menangani masalah pengelolaan sampah di kota Tebing Tinggi.

Kebijakan menentukan lokasi yang efisien dilakukan untuk memperkecil dampak-dampak negatif lingkungan dan sosial masyarakat. Penentuan lokasi sesuai dengan teori-teori lokasi tertentu sangat diperlukan dalam penentuan alternatif lokasi TPA.

Belum adanya alternatif Tempat Pembuangan Akhir (TPA) sampah kota Tebing Tinggi. Hal ini terlihat dari banyaknya penumpukan sampah yang overload menjadi dasar kami melakukan penelitian ini untuk mengetahui kesesuaian faktor-faktor standard dan teori dengan menggunakan metode Analitycal Hierarchy Process (AHP), sehingga bisa digunakan sebagai studi dalam evaluasi TPA Kota Tebing Tinggi dalam mengambil keputusan apakah akan memindahkan TPA ke tempat yang baru ataukan melakukan pengembangan terhadap TPA yang sudah ada.

Untuk itu perlu ditetapkan tujuan penelitian dalam permasalahan ini, yaitu :

- Identifikasi faktor lokasi yang berpengaruh dalam penentuan lokasi TPA.

- Penentuan kesesuaian antar faktor lokasi dengan pemilihan lokasi TPA, untuk mengetahui apakah lokasi TPA Tebing Tinggi memenuhi kriteria faktor lokasi berdasarkan standard dan teori dengan metode Analitycal Hierarchy Process (AHP).

Agar pembahasan dalam penelitian ini lebih fokus pada tujuan, maka dibatasi oleh :

- Penelitian ini dilakukan hanya pada Dinas Perumahan, Kawasan Permukiman dan Kebersihan Kota Tebing Tinggi dan yang diteliti adalah Tempat Pembuangan Akhir (TPA) sampah.

- Penelitian ini dilakukan hanya untuk menetukan kesesuaian atas faktor-faktor dan penentuan lokasi TPA Kota Tebing Tinggi dengan metode Analitycal Hierarchy Process (AHP).

\section{Studi Literatur}

\subsection{Definsi Sampah}

Menurut American Public Health Association (APHA, 1980), sampah adalah segala sesuatu yang tidak digunakan, tidak dipakai dan tidak disenangi yang dibuang dan berasal dari aktivitas manusia yang tidak terjadi dengan sendirinya. Secara umum, sampah adalah suatu benda yang berwujud padat yang dibuang karena sudah tidak berguna lagi dan berasal dari aktivitas manusia.

\subsection{Sumber Sampah}

Sumber sampah pada umumnya berkaitan dengan tata guna lahan, seperti berasal dari daerah perumahan dan permukiman, perkantoran, kawasan perdagangan dan jasa, kawasan komersial, dan lain-lain. Sumber-sumber sampah ini dapat dikembangkan sejalan dengan perkembangan tata guna lahannya. Sumber sampah dapat diklasifikasikan menjadi beberapa bagian, antara lain :

a. Daerah Perumahan dan Permukiman

b. Sampah yang berasal dari perumahan dan permukiman biasanya adalah sampah rumah tangga. Sampah rumah tangga ini berasal dari aktivitas rumah atau dapur serta aktivitas rumah tangga lainnya. Jenis sampah yang dihasilkan berupa sampah basah dan sampah kering atau debu.

c. Daerah Komersial

d. Sampah yang dihasilkan dari daerah komersial ini biasanya berasal dari aktivitas perdagangan dan jasa, misalnya dari pasar, pertokoan, restoran dan perusahaan.

e. Daerah non Komersial

f. Sumber sampah dari daerah non komersial ini biasanya berasal dari perkantoran, sekolah, tempat peribadatan dan rumah sakit. Jenis sampah yang dihasilkan dari daerah non komersial ini biasanya berupa sampah kering.

g. Sampah Jalan dan Tempat-tempat Terbuka

h. Sumber sampah dari kategori ini berasal dari penyapuan jalan-jalan, trotoar, dan taman. Jenis sampah ini biasanya dihasilkan sampah jalan pada umumnya adalah berupa sampah organik dan debu-debu jalanan. 
i. Daerah Industri

j. Sumber sampah ini berasal dari perusahaan bidang industri berat, industri ringan, dan pabrik-pabrik. Jenis sampah yang dihasilkan tergantung dari bahan baku yang digunakan industri tersebut. Rata-rata jenis sampah yang berasal dari daerah industri adalah berupa limbah.

k. Daerah Tempat Pembangunan, Pemugaran, dan Pembongkaran

1. Sampah yang berasal dari tempat-tempat ini rata-rata adalah berupa sampah material atau bahan-bahan bangunan yang mangkrak di sekitar daerah pembangunan. Jenis sampah yang dihasilkan dari lokasi ini biasanya tergantung dari bahan bangunan yang digunakan. Misalnya yaitu beton-beton, kayu, batu bata, dan yang lain-lain.

\subsection{Faktor-faktor yang Mempengaruhi Timbulan Sampah}

Timbulan sampah adalah sejumlah sampah yang dihasilkan oleh suatu aktivitas dalam kurun waktu tertentu, atau dengan kata lain banyaknya sampah yang dihasilkan dalam satuan berat (kilogram) atau volume (liter). Manfaat mengetahui banyaknya timbulan sampah adalah untuk menunjang penyusunan sistem pengolahan persampahan di suatu wilayah, data yang tersedia dapat digunakan sebagai bahan penyusun solusi alternatif sistem pengolahan sampah, yaitu pemilihan peralatan, perencanaan rute pengangkutan, fasilitas untuk daur ulang, dan luas serta jenis Tempat Pembuangan Akhir (TPA).

Adapun faktor-faktor yang mempengaruhi besarnya timbulan sampah antara lain adalah :

a. Jumlah penduduk

Semakin banyaknya penduduk menempati suatu wilayah, maka akan semakin banyak pula sampah yang dihasilkan. Bentuk pengelolaan sampah ini semestinya mengacu oleh faktor laju pertambahan penduduk di suatu wilayah

b. Keadaan sosial ekonomi masyarakat

Semakin tinggi keadaan sosial ekonomi masyarakat maka semakin banyak pula jumlah per kapita sampah yang dihasilkan. Kualitas sampah juga akan menyesuaikan dengan keadaan sosial ekonomi masyarakat. Kualitas sampah yang dihasilkan pada umumnya bersifat tidak dapat membusuk. Perubahan kualitas sampah ini tergantung pada bahan-bahan yang tersedia, peraturan yang berlaku serta kesadaran masyarakat akan persoalan persampahan

c. Kemajuan teknologi

Kemajuan teknologi akan menambah jumlah maupun kualitas sampah karena pemakaian bahan baku yang semakin banyak dan beragam, cara pengepakan dan produk manufaktur yang semakin beragam pula.

Pembuangan akhir merupakan proses akhir dalam sistem pengolahan sampah pada suatu tempat yang telah disiapkan dengan pertimbangan keamanan dan dapat mengurangi dampak negatif sampah terhadap lingkungan yang berada di sekitarnya.

\subsection{Metode Pembuangan Sampah}

Pembuangan sampah mengenal beberapa metode dalam pelaksanaanya yaitu :

a. Open Dumping

Open Dumping atau pembuangan terbuka merupakan cara pembuangan sederhana dimana sampah hanya dihamparkan pada suatu lokasi, dibiarkan terbuka tanpa pengaman dan ditinggalkan setelah lokasi tersebut penuh. Masih ada Pemda yang menerapkan sistem seperti ini karena alasan keterbatasan sumber daya (manusia, dana, dll).

Cara ini tidak direkomendasikan lagi mengingat banyaknya potensi pencemaran lingkungan yang ditimbulkannya seperti :

- Perkembangan vektor penyakit seperti lalat, tikus, dll.

- Polusi udara oleh baud an gas yang dihasilkan.

- Polusi air akibat lindi (cairan sampah) yang timbul.

b. Control Landfill

- Estetika lingkungan yang buruk karena pemandangan yang kotor.

Control Landfill merupakan peningkatan dari open dumping dimana secara periodik sampah yang telah tertimbun ditutup dengan lapisan tanah untuk mengurangi potensi gangguan lingkungan yang ditimbulkan. Dalam operasionalnya juga dilakukan perataan dan pemadatan sampah untuk meningkatkan efesiensi pemanfaatan lahan dan kestabilan permukaan TPA.

Di Indonesia, metode control landfill dianjurkan untuk ditetapkan di kota sedang dan kota kecil. Untuk dapat melaksanakan metode ini diperlukan penyediaan beberapa fasilitas diantaranya : 
- Saluran drainase untuk mengendalikan aliran air hujan.

- Saluran pengumpul lindi dan kolam penampungan.

- Pos pengendalian operasional.

- Fasilitas pengendalian gas metan.

- Alat berat.

\section{c. Sanitary Landfill}

Metode ini merupakan metode standar yang dipakai secara internasional dimana penutupan sampah dilakukan setiap hari sehingga potensi gangguan yang timbul dapat diminimalkan. Namun demikian diperlukan penyediaan prasarana dan sarana yang cukup mahal bagi penerapan metode ini sehingga sampai saat ini baru dianjurkan untuk kota-kota besar dan metropolitan.

\subsection{Tata Cara Pemilihan Lokasi Tempat Pembuangan Akhir Sampah (SNI 03-3241-1994)}

Tempat Pembuangan Akhir (TPA) merupakan tempat dimana sampah mencapai tahap akhir dalam pengelolaannya, dimana diawali dari sumber, pengumpulan, pemindahan atau pengangkutan, serta pengolahan dan pembuangan. TPA merupakan tempat dimana sampah diisolasi secara aman agar tidak menimbulkan kerusakan atau dampak negatif terhadap lingkungan sekitarnya. Oleh karena itu, diperlukan penyediaan fasilitas dan penanganan yang benar agar pengelolaan sampah tersebut dapat dilaksanakan dengan baik.

Penentuan Tempat Pembuangan Akhir (TPA) sampah harus mengikuti persyaratan dan ketentuan-ketentuan yang telah ditetapkan pemerintah melalui SNI nomor 03-3241-1994 tentang tata cara pemilihan lokasi TPA sampah. Berdasarkan Tata Cara Pemilihan Lokasi Tempat Pembuangan Akhir Sampah (SNI 03-3241-1994), kriteria penggolongan lokasi TPA dapat dibagi kedalam tiga bagian yaitu :

1. Kriteria Regional, yaitu kriteria yang digunakan untuk menentukan zona layak atau tidak layak sebagai berikut :

a. Kondisi geologi

- Tidak berlokasi di zona holocene fault

- Tidak boleh di zona bahaya geologi

b. Kondisi hidrogeologi

- Tidak boleh mempunyai muka tanah kurang dari 3 meter

- Tidak boleh kehalusan tanah lebih besar dari $10-6 \mathrm{~cm} / \mathrm{det}$

- Jarak antara sumber air minum harus lebih besar dari 100 meter di hilir aliran

- Dalam hal tidak ada zona yang memenuhi kriteria diatas, harus diadakan masukan teknologi.

c. Kemiringan zona harus kurang dari $20 \%$

d. Jarak dari lapangan terbang harus lebih besar dari 3000 meter untuk penerbangan turobjek dan lebih besar dari 1500 meter untuk jenis lain

e. Tidak boleh pada daerah lindung/cagar alam dan didaerah banjir dengan periode ulang 25 tahun.

2. Kriteria penyisih, yaitu kriteria yang digunakan untuk memilih lokasi terbaik yaitu terdiri dari kriteria regional ditambah dengan kriteria berikut :

a. Iklim

- Hujan : intensitas hujan semakin kecil dinilai semakin baik

- Angin : arah angin dominan tidak menuju ke permukiman dinilai semakin baik

b. Utilitas, tersedia lebih lengkap dinilai semakin baik

c. Lingkungan biologi

- Habitat : kurang bervariasi dinilai semakin baik

- Daya dukung : kurang menunjang kehidupan flora dan fauna, dinilai semakin baik

d. Kondisi

- Produktivitas tanah : tidak produktif dinilai lebih baik

- Kapasitas dan umur : dapat menampung lahan lebih banyak dan lebih lama dinilai lebih baik

- Ketersediaan tanah penutup : dapat menampung lahan lebih banyak dan lebih lama lebih baik

- Status lahan : makin bervariasi dinilai tidak baik

e. Demografi, kepadatan penduduk lebih rendah dinilai semakin baik

f. Batas administrasi, dalam batas administrasi dinilai semakin baik 
g. Kebisingan, semakin banyak zona penyangga dinilai semakin baik

h. Bau, semakin banyak zona penyangga dinilai semakin baik

i. Estetika, semakin tidak terlihat dari luar dinilai semakin baik

j. Ekonomi, semakin kecil biaya satuan pengelolaan sampah (per $\mathrm{m}^{3} /$ ton) dinilai semakin baik.

3. Kriteria penetapan, yaitu kriteria yang digunakan oleh instansi berwenang untuk menyetujui dan menetapkan lokasi terpilih sesuai dengan kebijakan instansi yang berwenang setempat dan ketentuan yang berlaku.

\subsection{Teori Pengambilan Keputusan}

Pada umumnya suatu keputusan dibuat dalam rangka untuk memecahkan permasalahan atau persoalan (problem solving), setiap keputusan yang dibuat pasti ada tujuan yang akan dicapai. Di dalam dunia yang modern ini, kehidupan menuntut banyak sekali keputusan yang harus dibuat, baik di dalam rumah tangga, di kantor atau di dalam organisasi (departemen dan industri pemerintah, perusahaan, perguruan tinggi) atau di dalam masyarakat dimana kita bergaul. Keputusan dibuat oleh individu (perseorangan), organisasi, kelompok individu, negara dengan satu tujuan atau lebih yang hendak dicapai.

Inti dari pengambilan keputusan ialah terletak dalam perumusan berbagai alternatif tindakan sesuai dengan yang sedang dalam perhatian dan dalam pemilihan alternatif yang tepat setelah suatu evaluasi (penilaian) mengenai efektivitasnya dalam mencapai tujuan yang dikehendaki pengambil keputusan. "Salah satu komponen terpenting dari proses pembuatan keputusan ialah kegiatan pengumpulan informasi dari mana suatu apresiasi mengenai situasi keputusan dapat dibuat.

Apabila informasi yang cukup dapat dikumpulkan guna memperoleh suatu spesifikasi yang lengkap dari semua alternatif dan tingkat keefektivannya dalam situasi yang sedang menjadi perhatian, proses pembuatan atau pengambilan keputusan relatif sangatlah mudah. Akan tetapi di dalam praktiknya sangat tidak mungkin mengumpulkan informasi secara lengkap, mengingat terbatasnya dana, waktu dan tenaga.

\subsection{Analitycal Hierarchy Process (AHP)}

Analitycal Hierarchy Process (AHP) adalah metode untuk memecahkan suatu situasi yang komplek tidak terstruktur kedalam beberapa komponen dalam susunan yang hirarki, dengan memberi nilai subjektif tentang pentingnya setiap variabel secara relatif, dan menetapkan variabel mana yang memiliki prioritas paling tinggi guna mempengaruhi hasil pada situasi tersebut. AHP merupakan pengambilan keputusan yang efektif atas persoalan kompleks dengan jalan menyederhanakan dan mempercepat proses pengambilan keputusan yang kita alami.AHP sudah sangat banyak digunakan, baik untuk persoalan bisnis, persoalan di instansi pemerintah, maupun penelitian di perguruan-perguruan tinggi.

\subsection{Prinsip Dasar dan Langkah-langkah Menggunakan AHP}

Ada tiga prinsip dasar Proses Hirarki Analitik, yaitu : (Saaty, 1993)

1. Prinsip Menyusun Hirarki

Prinsip menyusun hirarki adalah dengan menggambarkan dan menguraikan secara hirarki, dengan cara memecahkan persoalan menjadi beberapa gugusan yang homogen dan membagi lagi gugusan ini menjadi gugusangugusan yang lebih kecil. Caranya dengan memperincikan pengetahuan, pikiran kita yang kompleks kedalam bagian elemen pokoknya, lalu bagian ini kedalam bagian-bagiannya, dan seterusnya secara hirarki (Saaty, 1993).Istilah yang digunakan AHP untuk level hirarki adalah :

- Hirarki Level 1 : Tujuan (objektif)

- Hirarki Level 2 : Kriteria

- Hirarki Level 3 : Alternatif-alternatif

Contoh hirarki : 


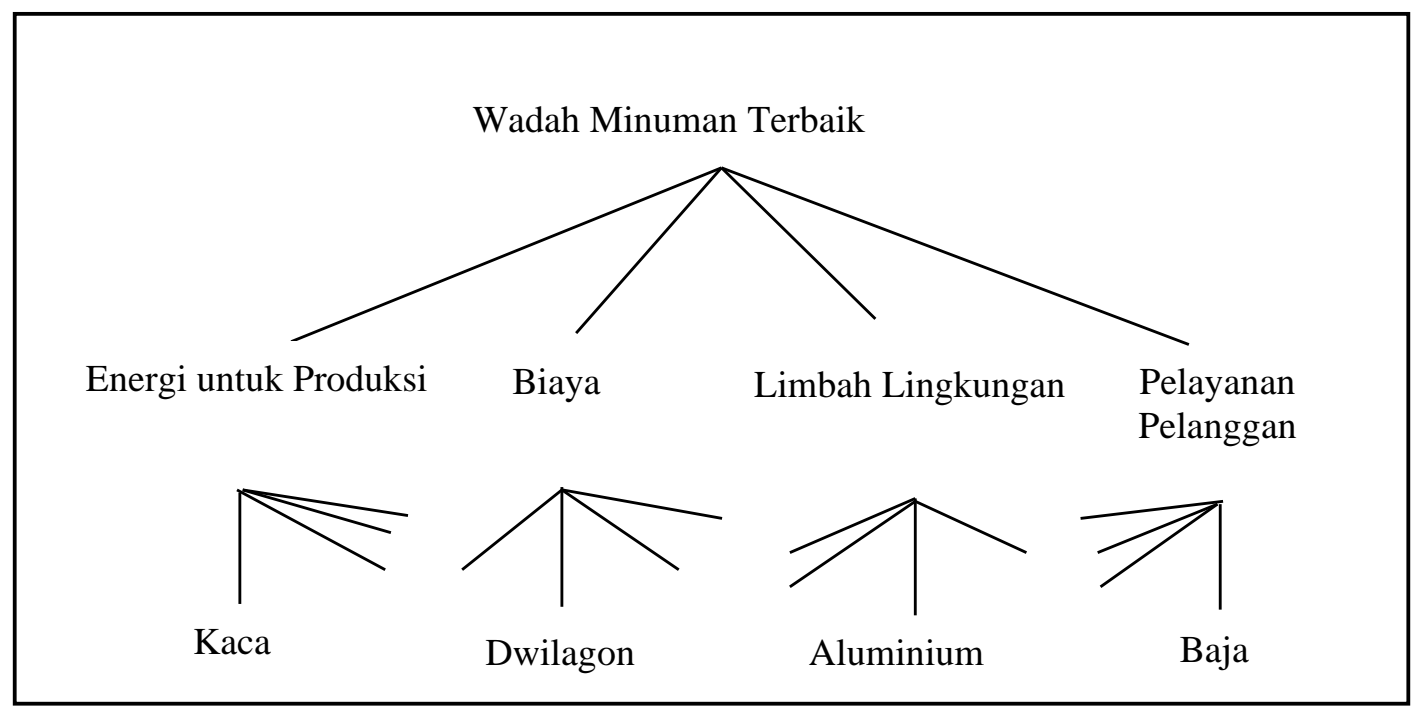

Gambar 1. Hirarki untuk Memilih Wadah Minuman

2. Prinsip Menentukan Prioritas

Prinsip menentukan prioritas yaitu menentukan peringkat elemen-elemen menurut relatif pentingnya. Setelah menyusun hirarki, selanjutnya memberikan penilaian tentang kepentingan relatif dua elemen pada suatu tingkat tertentu dalam kaitannya dengan tingkat diatasnya. Penilaian ini merupakan inti dari AHP, karena ia akan berpengaruh terhadap prioritas elemen-elemen. Hasil penilaian ini lebih mudah dilihat bila disajikan dalam bentuk matriks (tabel) yang diberi nama matriks berpasangan (pairwise comparison). Pertanyaan yang biasa dilakukan dalam menyusun skala kepentingan adalah :

(1) Elemen mana yang lebih (penting/disukai/mungkin/...),

(2) Berapa kali lebih (penting/disukai/mungkin/...)?

Proses pembandingan berpasangan ini dimulai pada puncak hirarki untuk memilih kriteria $\mathrm{C}$, atau sifat, yang akan digunakan untuk melakukan pembandingan yang pertama. Lalu dari tingkat tempat dibawahnya, ambil elemen-elemen yang akan dibandingkan : A1, A2, A3, dan sebagainya. katakanlah ada lima elemen. Susun elemen-elemen ini pada sebuah matrik seperti gambar dibawah ini.

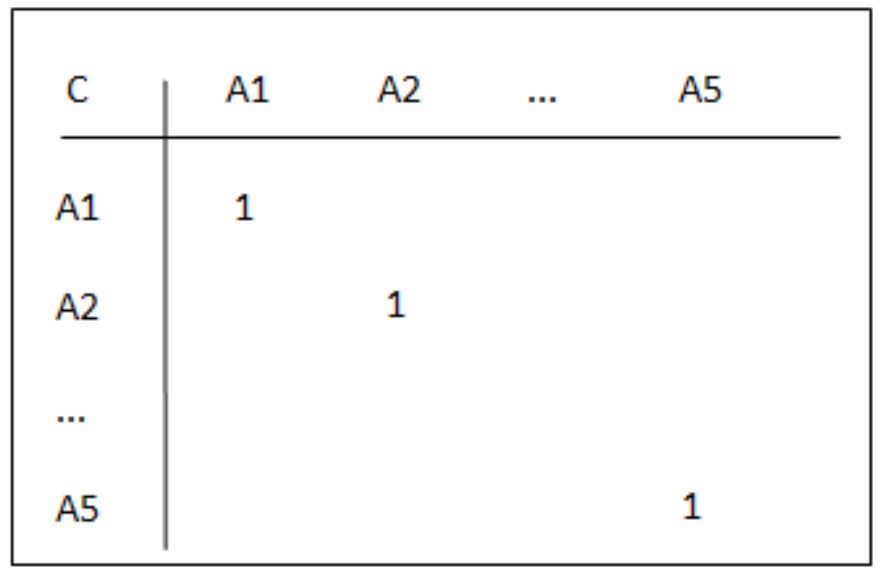

Gambar 2. Contoh Matriks untuk Pembanding Berpasangan

Dalam matriks ini, bandingkan elemen A1 dengan kolom disebelah kiri dengan elemen A1, A2, A3, dan seterusnya yang terdapat dibaris atas berkenaan dengan sifat $\mathrm{C}$ disudut kiri atas. Lalu ulangi dengan elemen $\mathrm{A} 2$ dan seterusnya.

Untuk mengisi matriks banding berpasangan itu, digunakan bilangan untuk menggambarkan relatif pentingnya suatu elemen di atas yang lainnya. Skala mendefinisikan dan menjelaskan nilai 1 sampai dengan 9 yang ditetapkan 
bagi pertimbangan dalam membandingkan pasangan elemen yang sejenis di setiap tingkat hirarki terhadap suatu kriteria yang berada setingkat di atasnya.

Untuk memperoleh perangkat prioritas menyeluruh bagi suatu persoalan keputusan, kita harus menyatukan atau mensintesis pertimbangan yang dibuat dalam melakukan pembandingan berpasang, yaitu kita harus melakukan pembobotan dan penjumlahan untuk menghasilkan satu bilangan tunggal yang menunjukkan prioritas setiap elemen.

Formulasi matematik pada AHP dilakukan dengan menggunakan suatu matriks. Misalkan, dalam suatu sub sistem operasi terdapat $\mathrm{n}$ elemen operasi, yaitu elemen A1, A2, ., An, maka hasil perbandingan secara berpasang elemenelemen operasi tersebut akan membentuk matriks perbandingan. Perbandingan berpasangan dimulai dari tingkat hirarki paling tinggi, dimana kriteria digunakan sebagai dasar pembuatan perbandingan.

Tabel 1. Skala Banding Secara Berpasang

\begin{tabular}{|c|c|c|}
\hline $\begin{array}{l}\text { Intensitas } \\
\text { Pentingnya }\end{array}$ & Definisi & Penjelasan \\
\hline 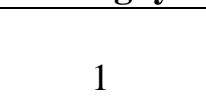 & Sama pentingnya & $\begin{array}{l}\text { Dua elemen mempunyai pengaruhn yang } \\
\text { sama }\end{array}$ \\
\hline 3 & Sedikit lebih penting & $\begin{array}{l}\text { Pengalaman dan penilaian sedikit memihak } \\
\text { satu elemen atas elemen pasangannya }\end{array}$ \\
\hline 5 & Lebih penting & $\begin{array}{l}\text { Pengalaman dan penilaian sangat memihak } \\
\text { satu elemen atas elemen pasangannya }\end{array}$ \\
\hline 7 & Sangat penting & $\begin{array}{l}\text { Satu elemen sangat disukai dan secara praktis } \\
\text { dominasinya sangat nyata atas elemen } \\
\text { pasangannya }\end{array}$ \\
\hline 9 & Mutlak lebih penting & $\begin{array}{l}\text { Satu elemen terbukti mutlak lebih disukai } \\
\text { dibandingkan dengan pasangannya, pada } \\
\text { keyakinan tinggi }\end{array}$ \\
\hline $2,4,6,8$ & $\begin{array}{c}\text { Nilai-nilai antara di antara } \\
\text { dua pertimbangan yang } \\
\text { berdekatan }\end{array}$ & $\begin{array}{l}\text { Kompromi diperlukan antara dua } \\
\text { pertimbangan }\end{array}$ \\
\hline Kebalikan & \multicolumn{2}{|c|}{$\begin{array}{l}\text { Jika untuk aktivitas } i \text { mendapat satu angka dibanding dengan antivitas } j \text {, maka } \\
j \text { mempunyai nilai kebalikannya bila dibandingkan dengan } i\end{array}$} \\
\hline
\end{tabular}

\begin{tabular}{|l|ccll|}
\hline & A1 & A2 & $\ldots$ & An \\
\hline & & & & \\
A1 & a11 & a12 & $\ldots$ & a1n \\
A2 & a21 & a22 & $\ldots$ & a2n \\
$\ldots$ & an1 & an2 & $\ldots$ & ann \\
& & & & \\
\end{tabular}

Gambar 3. Matriks Perbandingan Berpasangan

Nilai (judgment) perbandingan secara berpasang antara (wi, wj) dapat dipresentasikan seperti matriks tersebut. wi $/ \mathrm{wj}=\mathrm{a}(\mathrm{i}, \mathrm{j}) ; \mathrm{i}, \mathrm{j}=1,2, \ldots, \mathrm{n}$ 
Dalam hal ini matriks perbandingan adalah matriks A dengan unsur- unsurnya adalah aij, dengan $\mathrm{i}, \mathrm{j}=$ $1,2, \ldots$, n.unsur-unsur matriks tersebut diperoleh dengan membandingkan satu elemen operasi terhadap elemen operasi lainnya untuk tingkat hirarki yang sama. Semua unsur diagonal matriks perbandingan sama dengan 1 , misalnya unsur a11 adalah perbandingan elemen operasi A1 dengan elemen operasi A1 sendiri, sehingga nilai unsur a11 adalah sama dengan 1. Nilai unsur a12adalah perbandingan kepentingan elemen operasi A1 terhadap elemen operasi A2. Besar nilai a21 adalah 1 / a12, yang menyatakan tingkat intensitas kepentingan elemen operasi A2 terhadap elemen operasi A1.

Bila vektor pembobotan elemen-elemen operasi $A 1, A 2, \ldots$, An dinyatakan sebagai vektor $W=(W 1, W 2, \ldots, W n)$ , maka nilai intensitas kepentingan elemen operasi A1 dibandingkan A2 dapat dinyatakan sebagai perbandingan bobot elemen operasi A1 terhadap A2 yakni W1 / W2 yang sama dengan a12, sehingga dapat dinyatakan,

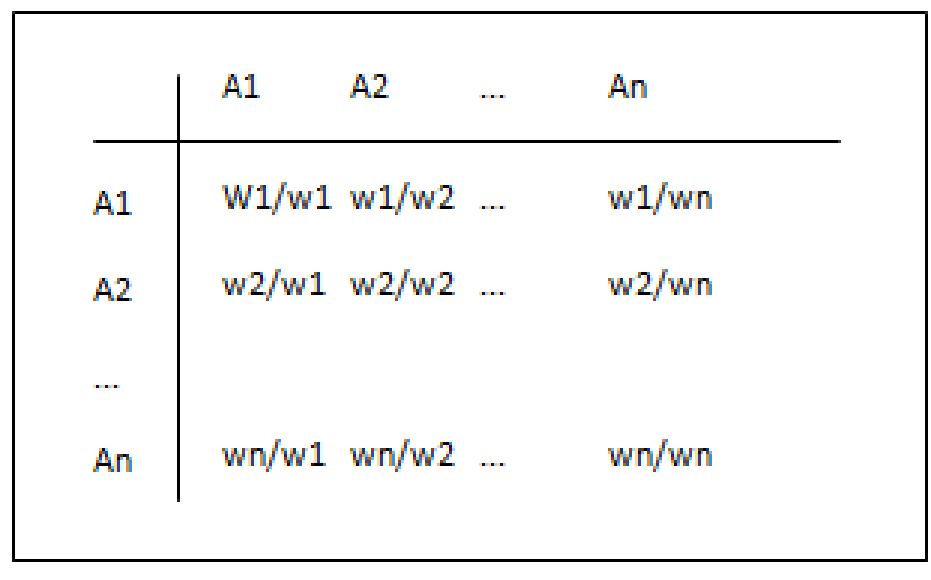

Gambar 4. Matriks Perbandingan Preferensi

Nilai-nilai wi/wj dengan $\mathrm{i}, \mathrm{j}=1,2, \ldots, \mathrm{n}$, dijajagi dari partisipan / responden, yaitu orang yang berkompeten dalam permasalahan yang dianalisis.

Bila matriks ini dikalikan dengan vector kolom $\mathrm{W}=(\mathrm{W} 1, \mathrm{~W} 2, \ldots, \mathrm{Wn})$, seperti yang terlihat pada gambar berikut ini

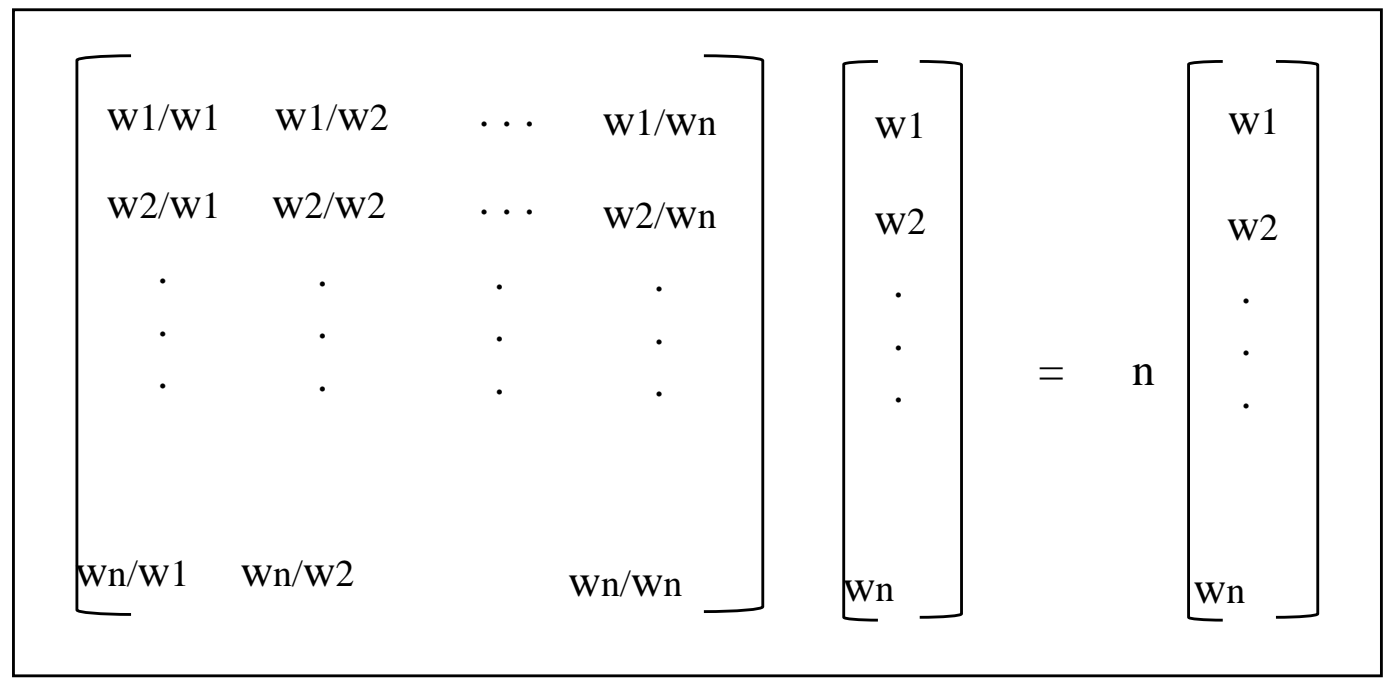

Gambar 5. Bentuk Perkalian Matriks

Sehingga diperoleh hubungan:

$$
\mathrm{AW}=\mathrm{nW}
$$

Bila matriks A diketahui dan ingin diperoleh nilai W, maka dapat diselesaikan melalui persamaan: 
Dimana I adalah matriks identitas.

$$
[\mathrm{A}-\mathrm{nI}] \mathrm{W}=0
$$

Persamaan (2) dapat menghasilkan solusi yang tidak nol bila (jika dan hanya jika) $\mathrm{n}$ merupakan eigen value dari A dan $\mathrm{W}$ adalah eigen vector-nya.

Setelah eigen value matriks perbandingan A tersebut diperoleh, misalnya $\lambda 1, \lambda 2, \ldots, \lambda \mathrm{n}$, dan berdasarkan matriks A yang mempunyai keunikan, yaitu aii $=1$ dengan $\mathrm{i}=1,2, \ldots, \mathrm{n}$, maka :

$$
\sum_{i=1}^{n} \lambda 1=\mathrm{n}
$$

Disini semua eigen value bernilai nol, kecuali satu yang tidak nol, yaitu eigen value maksimum. Kemudian jika penilaian yang dilakukan konsisten, akan diperoleh eigen value maksimum dari A yang bernilai $n$.

Untuk mendapatkan $\mathrm{W}$, maka dapat dilakukan dengan mendistribusikan harga eigen value maksimum pada persamaan:

Selanjutnya persamaan (2) dapat diubah menjadi:

$$
\mathrm{AW}=\lambda \text { maks } \mathrm{W}
$$

$$
[\mathrm{A}-\lambda \text { maks I }] \mathrm{W}=0
$$

Untuk memperoleh harga nol, maka yang perlu di set adalah:

$$
\mathrm{A}-\lambda \text { maks } \mathrm{I}=0
$$

Berdasarkan persamaan (4) akan diperoleh harga $\lambda$ maks dengan memasukkan harga $\lambda$ maks ke persamaan (3) dan ditambah dengan persamaan:

$$
\sum_{i=1}^{n} W i=1
$$

Maka akan diperoleh bobot masing-masing elemen operasi (Wi dengan $\mathrm{I}=1,2, \ldots, \mathrm{n}$ ) yang merupakan eigen vektor yang bersesuaian dengan eigen value maksimum.

3. Konsistensi Logis

Dalam persoalan pengambilan keputusan, mungkin penting untuk mengetahui betapa baiknya konsistensi kita, karena mungkin kita tak mau keputusan itu didasarkan atas pertimbangan yang mempunyai konsistensi yang begitu rendah sehingga nampak seperti pertimbangan acak.

Matriks bobot yang diperoleh dari hasil perbandingan secara berpasangan tersebut harus mempunyai hubungan cardinal dan ordinal sebagai berikut :

$$
\begin{array}{lcl}
\text { Hubungan Kardinal } & : & \text { aij . ajk }=\text { aik } \\
\text { Hubungan Ordinal } & : & \mathrm{Ai}>\mathrm{Aj}>\mathrm{Aj}>\mathrm{Ak} \text { ' maka } \mathrm{Ai}>\mathrm{Ak}
\end{array}
$$

Hubungan diatas dapat dilihat dari dua hal sebagai berikut :

a. Dengan melihat preferensi multiplikatif, misalnya bila anggur lebih enak 4 kali dari mangga, dan mangga lebih enak 2 kali dari pisang, maka anggur lebih enak 8 kali dari pisang.

b. Dengan melihat preferensi transitif, misalnya anggur lebih enak dari mangga, dan mangga lebih enak dari pisang, maka anggur lebih enak dari pisang.

Pada kenyataan, akan terjadi beberapa penyimpangan dari hubungan tersebut, sehingga matriks tersebut tidak konsisten sempurna. Hal ini terjadi karena ketidakkonsistenan dalam preferensi seseorang.

Dalam teori matriks diketahui bahwa kesalahan kecil pada koefisien akan menyebabkan penyimpangan kecil pula pada eigen value. Dengan mengkombinasikan apa yang telah diuraikan sebelumnya, jika diaogal utama dari matriks A bernilai satu dan jika A konsisten maka penyimpangan kecil dari $\mathrm{A}_{\mathrm{ij}}$ akan tetap menunjukkan eigen value terbesar, $\lambda$ maks', nilainya akan mendekati $n$ dan eigen value sisanya akan mendekati nol.

Penyimpangan dari konsistensi dinyatakan dengan indeks konsistensi, dengan persamaan:

Dimana: $\lambda$ maks $=$ eigen value maksimum

$$
\mathrm{CI}=\frac{\lambda m a k s-n}{n-1}
$$

$$
\mathrm{n} \quad=\text { ukuran matriks }
$$

Indeks Konsistensi (CI), matriks random dengan skala penilaian (1 sampai dengan 9) beserta kebalikannya sebagai Indeks Random (RI). Berdasarkan perhitungan Saaty dengan menggunakan 500 sampel, jika "judgment" numerik diambil secara acak dari skala $1 / 9,1 / 8, \ldots, 1,2, \ldots, 9$ akan diperoleh rata-rata konsistensi untuk matriks dengan ukuran yang berbeda, sebagai berikut: 
Tabel 2. Nilai Indeks Random

\begin{tabular}{cc}
\hline Ukuran Matriks & Indeks Random \\
\hline 1,2 & 0.00 \\
3 & 0.58 \\
4 & 0.90 \\
5 & 1.12 \\
6 & 1.24 \\
7 & 1.32 \\
8 & 1.41 \\
9 & 1.45 \\
10 & 1.49 \\
11 & 1.51 \\
12 & 1.48 \\
13 & 1.56 \\
14 & 1.57 \\
15 & 1.59 \\
\hline
\end{tabular}

Perbandingan antara CI dan RI untuk suatu matriks didefinisikan sebagai Rasio Konsistensi (CR).

$$
\mathrm{CR}=\frac{C I}{R I}
$$

Saaty menetapkan bahwa penilaian suatu matriks perbandingan adalah konsistensi bila nilai $C R \leq 0.1$, sehingga hasil penilaian tersebut dapat diterima atau dipertanggungjawabkan. Jika tidak, maka pengambilan keputusan harus meninjau ulang masalah dan merevisi matriks perbandingan berpasangan.

\section{Metode Penelitian}

Metodologi penelitian merupakan proses pemecahan masalah yang digunakan untuk menyelesaikan persoalan yang timbul, yang disusun berdasarkan latar belakang dan tujuan yang ingin dicapai dengan menggunakan teori pendukung dalam pemecahan masalah, dan melakukan pengumpulan data baik melalui literature maupun melalui studi lapangan, melakukan pengolahan data sampai pada penarikan kesimpulan yang diteliti.

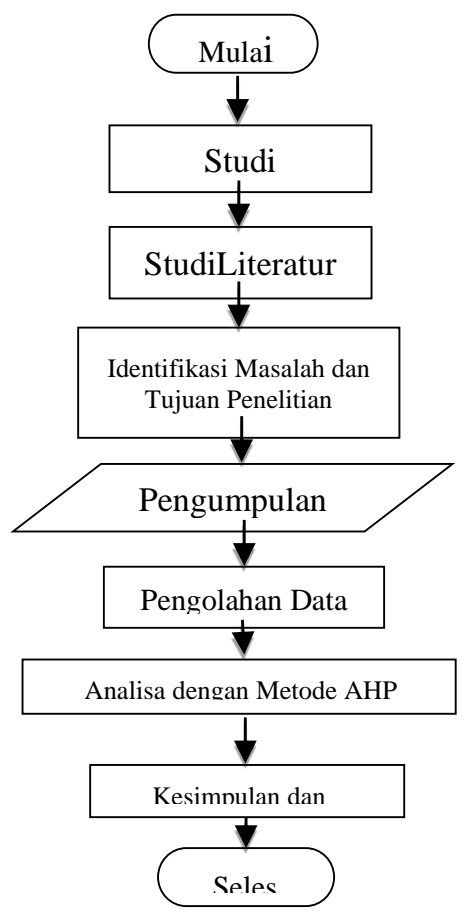

Gambar 6. Flowcart Penelitian 


\section{Hasil dan Pembahasan}

Kota Tebing Tinggi memiliki luas wilayah 38.438 Km2.Lokasi TPA Kota Tebing Tinggi saat ini terletak di Jl. Baja, Kel. Tebing Tinggi, Kec. Padang Hilir, Kota Tebing Tinggi tepatnya dekat dengan perbatasan Kabupaten Serdang Berdagai, dengan luas lahan 1,2 Ha dengan status milik pemerintah. Saat ini ketinggian dari timbunan sampah di TPA sudah mencapai 10-meter dari badan jalan. Metode pembuangan sampah di TPA dengan sistem Open Dumping(terbuka) yaitu sampah dibiarkan menumpuk begitu saja.

Jarak TPA terhadap permukiman 500 meter, $2 \mathrm{Km}$ dari jalan kota ke TPA, 1,5 Km dari jalan lintas ke TPA dan 1 Km dari tempat peribadatan. Penduduk Kota Tebing Tinggi tahun 2018 berjumlah 169,833 jiwa yang terdiri atas 82.315 penduduk laki-laki dan 87.518 penduduk perempuan dengan 5 kecamatan, dan 35 kelurahan.

Kapasitas sampah Kota Tebing Tinggi adalah 118,88 ton/hari. Namun hanya 103,04ton/hari sampah yang tercakup oleh armada sampah. Sisa dari sampah yang tidak tercakup oleh armada ini yaitu termasuk sampah olahan masyarakat, seperti dibakar, dibuang kesungai, dibuat pupuk rumahan, ataupun dibuat kerajinan rumah tangga. Sistem pengolahan pada sampah di Dinas Perumahan, Kawasan Permukiman dan Kebersihan Kota Tebing Tinggi ada 3, yaitu:

1. 3R (Reuse Reduce Recycle) atau biasa disebut menggunakan kembali, mengurangi, mengelola kembali.

2. Pengolahan sampah dinas melalui :

a. Bank sampah

b. Pengolahan kompos

3. Pengolahan sampah masyarakat :

a. Bank sampah

b. Pengolahan kompos

c. Koleksi kerajinan

Pemilihan responden ini berdasarkan pertimbangan bahwa responden:

- Terkait dengan proses masuknya sampah ke TPA

- Merupakan para pakar di instansi

Responden penelitian ini diambil dari para pakar.

Tabel 3. Daftar Responden

\begin{tabular}{|c|c|c|c|}
\hline No & Nama & Jabatan & Departemen \\
\hline 1 & Zubir Husni Harahap, SH & $\begin{array}{l}\text { Kepala Dinas Perumahan Kawasan Permukiman } \\
\text { dan Kebersihan Kota Tebing Tinggi }\end{array}$ & Kantor \\
\hline 2 & Hendra Wijaya, SE & $\begin{array}{l}\text { Kepala Bidang Kebersihan dan Persampahan Kota } \\
\text { Tebing Tinggi }\end{array}$ & Kantor \\
\hline 3 & Syafar Halomoan, ST & $\begin{array}{l}\text { Ketua Seksi Angkutan Dan TPA Kota Tebing } \\
\text { Tinggi }\end{array}$ & Kantor \\
\hline 4 & Andi Syahputra Pardede, ST & $\begin{array}{l}\text { Perencana Analisis Pembangunan TPA Kota } \\
\text { Tebing Tinggi }\end{array}$ & Kantor \\
\hline 5 & Agus Haryadi Syahputra & $\begin{array}{l}\text { Pengawas/KoordinatorPersampahan Kota Tebing } \\
\text { Tinggi }\end{array}$ & TPA \\
\hline 6 & Asrianto & $\begin{array}{l}\text { Pelaksana kegiatan/KoordinatorPersampahan Kota } \\
\text { Tebing Tinggi }\end{array}$ & TPA \\
\hline
\end{tabular}

Pada kuesioner terdapat beberapa kriteria utama yaitu Teknis, Lingkungan dan Sosial, dan Aksebilitas. Masingmasing kriteria akan dibagi lagi menjadi beberapa beberapa subkriteria. Kriteria utama, subkriteria, dan alternatif ini dipilih berdasarkan hasil diskusi terhadap para pakar di instansi.

Pada pengisian kuesioner, responden diminta untuk memberikan penilaian besarnya perbandingan berpasangan untuk kriteria dan subkriteria dan dilanjutkan pada penilaian terhadap penentuan TPA dilihat dari kriteria, subkriteria dan alternatif.

Dari hasil wawancara, didapatkan kriteria dan subkriteria yaitu sebagai berikut:

1. Kriteria Teknis

Teknis adalah struktur yang memiliki sumber-sumber yang berasal dari lingkungan. Teknis ini meliputi 4 subkriteria, yaitu :

a. Luas tanah 

b. Kemiringan tanah
c. Tidak dalam wilayah lindung
d. Tidak berada pada zona bahaya geologi

2. Kriteria Lingkungan dan Sosial

Lingkungan dan sosial tidak bisa dipisahkan dari kehidupan manusia. Lingkungan dan soasial sangatlah penting guna terciptanya kehidupan yang aman dan nyaman. Lingkungan dan sosial ini meliputi 3 subkriteria, yaitu:
a. Kepadatan penduduk
b. Jarak permukiman terhadap TPA
c. Bebas banjir

3. Kriteria Aksebilitas

Dalam menentukan TPA harus mempertimbangkan jarak TPA sebelum TPA dibuat. Aksebilitas ini meliputi 3 subkriteria, yaitu :
a. Lokasi mudah diakses
b. Lokasi terdekat dengan sumber sampah
c. Jauh dari jaringan jalan utama

4. Terdapat 2 alternatif, yaitu :

a. $\quad$ Pengembangan TPST (Tempat Pemrosesan Sampah Terpadu)

b. Membuka lahan TPA di daerah Kabupaten Serdang Bedagai

Setelah responden melakukan penilain matriks perbandingan berpasangan, dirata-ratakan dengan menggunakan rata-rata geometrik sehingga didapatkan perhitungan bobot kriteria utama, subkriteria dan alternatif.

Data dari perbandingan berpasangan kemudian diolah untuk mendapatkan pembobotan dari masing-masing kriteria utama dan pembobotan subkriteria. Berikut ini adalah contoh perhitungan pembobotan. Dengan menjumlahkan nilai aij pada setiap kolom matriks perbandingan berpasangan seperti pada table 2 sampai dengan tabel 8. di bawah ini.

\begin{tabular}{lccc}
\multicolumn{1}{c}{ Kriteria } & Tabel 4. Sintesis Matriks Kriteria Utama \\
& Teknis & $\begin{array}{c}\text { Lingkungan } \\
\text { dan Sosial }\end{array}$ & Aksebilitas \\
\hline Teknis & 1,00 & 1.1516 & 1,7099 \\
Lingkungan dan Sosial & 0,8683 & 1,00 & 1,4422 \\
Aksebilitas & 0,5848 & 0,6933 & 1,00 \\
Jumlah & 2,4531 & 2,8449 & 4,1521 \\
\hline
\end{tabular}

Tabel 5. Sintesis Matriks Subkriteria Teknis

\begin{tabular}{lcccc}
\hline \multicolumn{1}{c}{ Subkriteria } & A1 & A2 & A3 & A4 \\
\hline Luas tanah (A1) & 1,00 & 1,1224 & 0,9531 & 0,5848 \\
Kemiringan tanah (A2) & 0,8908 & 1,00 & 0,7418 & 0,7699 \\
Tidak dalam wilayah lindung (A3) & 1,0491 & 1,3480 & 1,00 & 0,8642 \\
Tidak berada pada zona bahaya geologi (A4) & 1,7099 & 1,2987 & 1,1570 & 1,00 \\
Jumlah & 4,6498 & 4,7691 & 3,8519 & 3,2189 \\
\hline
\end{tabular}

Tabel 6. Sintesis Matriks Subkriteria Lingkungan dan Sosial

\begin{tabular}{lccc}
\hline \multicolumn{1}{c}{ Subkriteria } & A1 & A2 & A3 \\
\hline Kepadatan penduduk (A1) & 1,00 & 1,00 & 0,7418 \\
Jarak permukiman terhadap TPA (A2) & 1,00 & 1,00 & 1,1649 \\
Bebas banjir (A3) & 1,3480 & 0,8583 & 1,00 \\
Jumlah & 3,348 & 2,8583 & 2,9067 \\
\hline
\end{tabular}


Tabel 7. Sintesis Matriks Subkriteria Aksebilitas

\begin{tabular}{lccc}
\hline \multicolumn{1}{c}{ Subkriteria } & $\mathbf{A 1}$ & $\mathbf{A 2}$ & $\mathbf{A 3}$ \\
\hline Lokasi mudah diakses (A1) & 1,00 & 0,8182 & 0,7974 \\
Lokasi terdekat dengan sumber sampah (A2) & 1,2222 & 1,00 & 1,6398 \\
Jauh dari jaringan jalan utama (A3) & 1,2540 & 0,6098 & 1,00 \\
Jumlah & 3,4762 & 2,2428 & 3,4372 \\
\hline \multicolumn{2}{c}{ Tabel 8. Sintesis Matriks Subkriteria Teknis Antar Luas } & Tanah Dengan Faktor Penentu TPA Baru \\
\hline \multicolumn{2}{c}{ Luas Tanah } & $\mathbf{A 1}$ & $\mathbf{A 2}$ \\
\hline Alternatif 1 (A1) & 1,00 & 0,9826 \\
Alternatif A2 (A2) & 1,0177 & 1,00 \\
Jumlah & 2,0177 & 2,9826 \\
\hline
\end{tabular}

Dengan membagi nilai aij dengan jumlah nilai kolom tersebut yang menghasilkan matriks ternomalisasi seperti pada tabel 9. sampai dengan tabel 13. berikut ini :

Tabel 9. Matriks Ternormalisasi Kriteria Utama

\begin{tabular}{lccc}
\hline \multicolumn{1}{c}{ Kriteria } & Teknis & $\begin{array}{c}\text { Lingkungan dan } \\
\text { Sosial }\end{array}$ & Aksebilitas \\
\hline Teknis & 0,4076 & 0,4047 & 0,4118 \\
Lingkungan dan Sosial & 0,3539 & 0,3515 & 0,3473 \\
Aksebilitas & 0,2383 & 0,2436 & 0,2408 \\
\hline
\end{tabular}

Tabel 10. Matriks Ternormalisasi Subkriteria Teknis

\begin{tabular}{lcccc}
\hline \multicolumn{1}{c}{ Subkriteria } & A1 & A2 & A3 & A4 \\
\hline Luas tanah (A1) & 0,2150 & 0,2353 & 0,2474 & 0,1816 \\
Kemiringan tanah (A2) & 0,1916 & 0,2097 & 0,1925 & 0,2391 \\
Tidak dalam wilayah lindung (A3) & 0,2256 & 0,2826 & 0,2596 & 0,2684 \\
Tidak berada pada zona bahaya geologi (A4) & 0,3677 & 0,2723 & 0,3003 & 0,3106 \\
\hline
\end{tabular}

Tabel 11. Matriks Ternormalisasi Subkriteria Lingkungan dan Sosial

\begin{tabular}{lccc}
\hline \multicolumn{1}{c}{ Subkriteria } & A1 & A2 & A3 \\
\hline Kepadatan penduduk (A1) & 0,2986 & 0,3498 & 0,2552 \\
Jarak permukiman terhadap TPA (A2) & 0,2986 & 0,3498 & 0,4007 \\
Bebas banjir (A3) & 0,4026 & 0,3002 & 0,3440 \\
\hline
\end{tabular}

Tabel 12. Matriks Ternormalisasi Subkriteria Aksebilitas

\begin{tabular}{lccc}
\hline \multicolumn{1}{c}{ Subkriteria } & A1 & A2 & A3 \\
\hline Lokasi mudah diakses (A1) & 0,2876 & 0,3648 & 0,2319 \\
Lokasi terdekat dengan sumber sampah (A2) & 0,3515 & 0,4458 & 0,4770 \\
Jauh dari jaringan jalan utama (A3) & 0,3607 & 0,2718 & 0,2909 \\
\hline
\end{tabular}

Tabel 13. Matriks Ternormalisasi Subkriteria Teknis Antar Luas Tanah Dengan Faktor Penentu

TPA Baru Terhadap Alternatif

\begin{tabular}{lccc}
\hline & Luas Tanah & A1 & A2 \\
\hline Alternatif 1 (A1) & 0,4956 & 0,4956 \\
Alternatif A2 (A2) & 0,5044 & 0,5044 \\
\hline
\end{tabular}


Menghitung rata-rata masing-masing baris dari matriks ternormalisasi seperti tabel 14. sampai dengan tabel 18 . di bawah ini.

Tabel 14. Perhitungan Bobot Kriteria Utama

\begin{tabular}{lcccc}
\hline \multicolumn{1}{c}{ Kriteria } & Teknis & $\begin{array}{c}\text { Lingkungan } \\
\text { dan Sosial }\end{array}$ & Aksebilitas & Bobot \\
\hline Teknis & 0,4076 & 0,4047 & 0,4118 & 0,4080 \\
Lingkungan dan Sosial & 0,3539 & 0,3515 & 0,3473 & 0,3509 \\
Aksebilitas & 0,2383 & 0,2436 & 0,2408 & 0,2409 \\
\hline
\end{tabular}

Tabel 15. Perhitungan Bobot Parsial Subkriteria Teknis

\begin{tabular}{lccccc}
\hline \multicolumn{1}{c}{ Subkriteria } & A1 & A2 & A3 & A4 & Bobot \\
\hline Luas tanah (A1) & 0,2150 & 0,2353 & 0,2474 & 0,1816 & 0,2198 \\
Kemiringan tanah (A2) & 0,1916 & 0,2097 & 0,1925 & 0,2391 & 0,2088 \\
Tidak dalam wilayah lindung (A3) & 0,2256 & 0,2826 & 0,2596 & 0,2684 & 0,2591 \\
Tidak berada pada zona bahaya geologi (A4) & 0,3677 & 0,2723 & 0,3003 & 0,3106 & 0,3127 \\
\hline
\end{tabular}

Tabel 16. Perhitungan Bobot Parsial Subkriteria Lingkungan dan Sosial

\begin{tabular}{lcccc}
\hline \multicolumn{1}{c}{ Subkriteria } & A1 & A2 & A3 & Bobot \\
\hline Kepadatan penduduk (A1) & 0,2986 & 0,3498 & 0,2552 & 0,3012 \\
Jarak permukiman terhadap TPA (A2) & 0,2986 & 0,3498 & 0,4007 & 0,3497 \\
Bebas banjir (A3) & 0,4026 & 0,3002 & 0,3440 & 0,3489 \\
\hline
\end{tabular}

Tabel 17. Perhitungan Bobot Parsial Subkriteria Aksebilitas

\begin{tabular}{lcccc}
\hline \multicolumn{1}{c}{ Subkriteria } & A1 & A2 & A3 & Bobot \\
\hline Lokasi mudah diakses (A1) & 0,2986 & 0,3498 & 0,2552 & 0,2948 \\
Lokasi terdekat dengan sumber sampah (A2) & 0,2986 & 0,3498 & 0,4007 & 0,4248 \\
Jauh dari jaringan jalan utama (A3) & 0,4026 & 0,3002 & 0,3440 & 0,3078 \\
\hline
\end{tabular}

Tabel 18. Perhitungan Bobot Subkriteria Teknis Antar Luas Tanah Dengan Faktor

Penentu TPA Baru Terhadap Alternatif

\begin{tabular}{lccc}
\hline \multicolumn{1}{c}{ Luas Tanah } & A1 & A2 & Bobot \\
\hline Alternatif 1 (A1) & 0,4956 & 0,4956 & 0,4956 \\
Alternatif A2 (A2) & 0,5044 & 0,5044 & 0,5044 \\
\hline
\end{tabular}

Dalam menentukan nilai bobot global adalah dengan melakukan perkalian bobot parsial dengan bobot hirarki diatasnya seperti pada tabel 19 .

Tabel 19. Hasil Perhitungan Bobot Kriteria Utama dan Subkriteria

\begin{tabular}{cclcc}
\hline Kriteria & \multirow{2}{*}{ Bobot } & \multicolumn{1}{c}{ Subkriteria } & $\begin{array}{c}\text { Bobot } \\
\text { Parsial }\end{array}$ & $\begin{array}{c}\text { Bobot } \\
\text { Global }\end{array}$ \\
& & & 0,2198 & 0,0896 \\
Teknis & \multirow{2}{*}{0,4080} & Luas Tanah & 0,2088 & 0,0851 \\
& & Kemiringan Tanah & 0,2591 & 0,1057 \\
& & Tidak Dalam Wilayah Lindung & 0,3127 & 0,1275 \\
Lingkungan & & Tidak Berada Pada Zona Bahaya Geologi & 0,3012 & 0,1056 \\
dan Sosial & \multirow{2}{*}{0,3509} & Kepadatan Penduduk & 0,3497 & 0,1227 \\
& & Jarak Permukiman Terhadap TPA & 0,3489 & 0,1224 \\
& & Bebas Banjir & 0,2948 & 0,0710 \\
Aksebilitas & 0,2409 & Lokasi Mudah Diakses & 0,4248 & 0,1023 \\
\hline
\end{tabular}




\begin{tabular}{|c|c|c|c|c|}
\hline \multirow{2}{*}{\multicolumn{3}{|c|}{ Jauh Dari Jaringan Jalan Utama }} & \multirow[t]{2}{*}{0,3078} & \multirow[t]{2}{*}{0,0741} \\
\hline & & dan Alternatif & & \\
\hline Subkriteria & $\begin{array}{c}\text { Bobot } \\
\text { Global }\end{array}$ & Alternatif & $\begin{array}{c}\text { Bobot } \\
\text { Parsial }\end{array}$ & $\begin{array}{l}\text { Bobot } \\
\text { Global }\end{array}$ \\
\hline \multirow[t]{2}{*}{ Luas Tanah } & 0,0896 & A1 & 0,4956 & 0,0444 \\
\hline & & $\mathrm{A} 2$ & 0,5044 & 0,0452 \\
\hline \multirow[t]{2}{*}{ Kemiringan Tanah } & 0,0851 & A1 & 0,5623 & 0,0479 \\
\hline & & $\mathrm{A} 2$ & 0,4377 & 0,0372 \\
\hline \multirow[t]{2}{*}{ Tidak Dalam Wilayah Lindung } & 0,1057 & A1 & 0,6535 & 0,0691 \\
\hline & & $\mathrm{A} 2$ & 0,3465 & 0,0366 \\
\hline \multirow[t]{2}{*}{ Tidak Berada Pada Zona Bahaya Geologi } & 0,1275 & A1 & 0,5948 & 0,0758 \\
\hline & & $\mathrm{A} 2$ & 0,4052 & 0,0517 \\
\hline \multirow[t]{2}{*}{ Kepadatan Penduduk } & 0,1056 & A1 & 0,7948 & 0,0839 \\
\hline & & $\mathrm{A} 2$ & 0,2052 & 0,0217 \\
\hline \multirow[t]{2}{*}{ Jarak Permukiman Terhadap TPA } & 0,1227 & A1 & 0,4711 & 0,0578 \\
\hline & & $\mathrm{A} 2$ & 0,5288 & 0,0649 \\
\hline \multirow[t]{2}{*}{ Bebas Banjir } & 0,1224 & A1 & 0,5169 & 0,0633 \\
\hline & & $\mathrm{A} 2$ & 0,4831 & 0,0591 \\
\hline \multirow[t]{2}{*}{ Lokasi Mudah Diakses } & 0,0710 & A1 & 0,5288 & 0,0375 \\
\hline & & $\mathrm{A} 2$ & 0,4711 & 0,0334 \\
\hline \multirow[t]{2}{*}{ Lokasi Terdekat Dengan Sumber Sampah } & 0,1023 & A1 & 0,4154 & 0,0425 \\
\hline & & $\mathrm{A} 2$ & 0,5846 & 0,0598 \\
\hline \multirow[t]{2}{*}{ Jauh Dari Jaringan Jalan Utama } & 0,0741 & A1 & 0,4142 & 0,0307 \\
\hline & & $\mathrm{A} 2$ & 0,5858 & 0,0434 \\
\hline
\end{tabular}

Bobot ini ditampilkan dalam struktru hirarki yang terlihat pada lampiran 1. Setelah besarnya bobot masingmasing kriteria utama dan subkriteria diperoleh, maka selanjutnya dihitung rasio konsistensinya untuk mengetahui apakah hasil pembobotan yang didapat sudah cukup konsisten. Sebagai parameternya adalah rasio konsistensi lebih kecil atau sama dengan $10 \%$. Setelah didapatkan rasio konsistensi untuk seluruh kriteria dan subkriteria, maka berikutnya adalah uji konsistensi, keseluruhan hirarki.

Rumus perhitungan rasio konsistensi (CR)

$$
\lambda \text { maks }=(\text { faktor bobot } \mathrm{x} \text { bobot }) 1+\ldots+(\text { faktor bobot } \mathrm{x} \text { bobot })_{\mathrm{n}}
$$

Perhitungan eigen value untuk kriteria utama

$\lambda$ maks $=(2,4531 \times 0,4080)+(2,8449 \times 0,3509)+(4,1521 \times 0,2409)$

$$
=3,0075
$$

\section{Perhitungan CI}

CI kriteria utama

$$
\begin{aligned}
\mathrm{CI} & =\frac{\lambda \text { maks }-n}{n-1} \\
& =\frac{3,0075-3}{3-1}=0,00375
\end{aligned}
$$

Perhitungan CR

$$
\mathrm{CR}=\mathrm{CI} / \mathrm{RCI}
$$

CR kriteria utama

$$
=\frac{0,00375}{0,58}=0,0065=0,65 \%
$$

Dengan cara yang sama maka didapatkan seluruh rasio konsistensi untuk seluruh sub kriteria dan alternatif. 


\section{Kesimpulan}

1. Setelah melakukan seluruh tahapan penelitian dengan metode AHP, maka terbentuklah sebuah kriteria penentuan TPA baru dengan 3 kriteria utama, yaitu kriteria teknis dengan bobot $40,8 \%$, kriteria lingkungan dan sosial dengan bobot 35,09\%, dan kriteria aksebilitas 24,09\%.

2. Berdasarkan perhitungan dengan menggunakan metode AHP, didapat sebuah keputusan bahwa instansi memilih alternatif 1 , yaitu melakukan pengembangan TPST dengan bobot dari setiap subkriteria terhadap alternatif 1 adalah $55,29 \%$.

\section{Referensi}

[1] Arfah, Mahrani. (2001) "Analisis Penentuan Prioritas Pengembangan Manajemen PD. Industri Jawa Barat dengan Menggunakan Metoda Proses Hirarki Analitik". Skripsi. Universitas Pasundan. Bandung.

[2] Diana (2018) "Metode \& Aplikasi Sistem Pendukung Keputusan" CV. BUDI UTAMA. Yogyakarta.

[3] Kafiati, Rena. (2017). "Kriteria Evaluasi Dan Peringkat Pemasok Dengan Menggunakan Metode AHP Dan TOPSIS Pada PT. Sumber Sawit Makmur”. Skripsi, Universitas Islam Sumatera Utara. Medan.

[4] Kursini (2007).” Konsep dan Aplikasi Sistem Pendukung Keputusan” CV. ANDI. Yogyakarta.

[5] Saaty, Thomas L. (1993) "Pengambilan Keputusan Bagi Para Pemimpin” PT. Pustaka Binaman Pressindo, Jakarta Pusat.

[6] Sugiarto, Dergibson Siagian, Lasmono Tri Sunaryanto, Deny S. Oetomo. (2003) "Teknik Sampling” PT. SUN. Jakarta.

[7] Supranto, J. (2005) “Teknik Pengambilan Keputusan” PT. Rineka Cipta, Jakarta.

[8] Ali Kusuma. (2015) “Analisis Faktor-Faktor Yang Mempengaruhi Pemilihan Lokasi TPA Benowo" Surabaya di https://www.academia.edu

[9] https://depokbebassampah.wordpress.com/kajian/rencana/induk-persampahan/5-kriteria-tpa/

Lampiran 1. Struktur Hirarki Studi Penentuan Tempat Pembuangan Akhir Sampah Kota Tebing Tingg

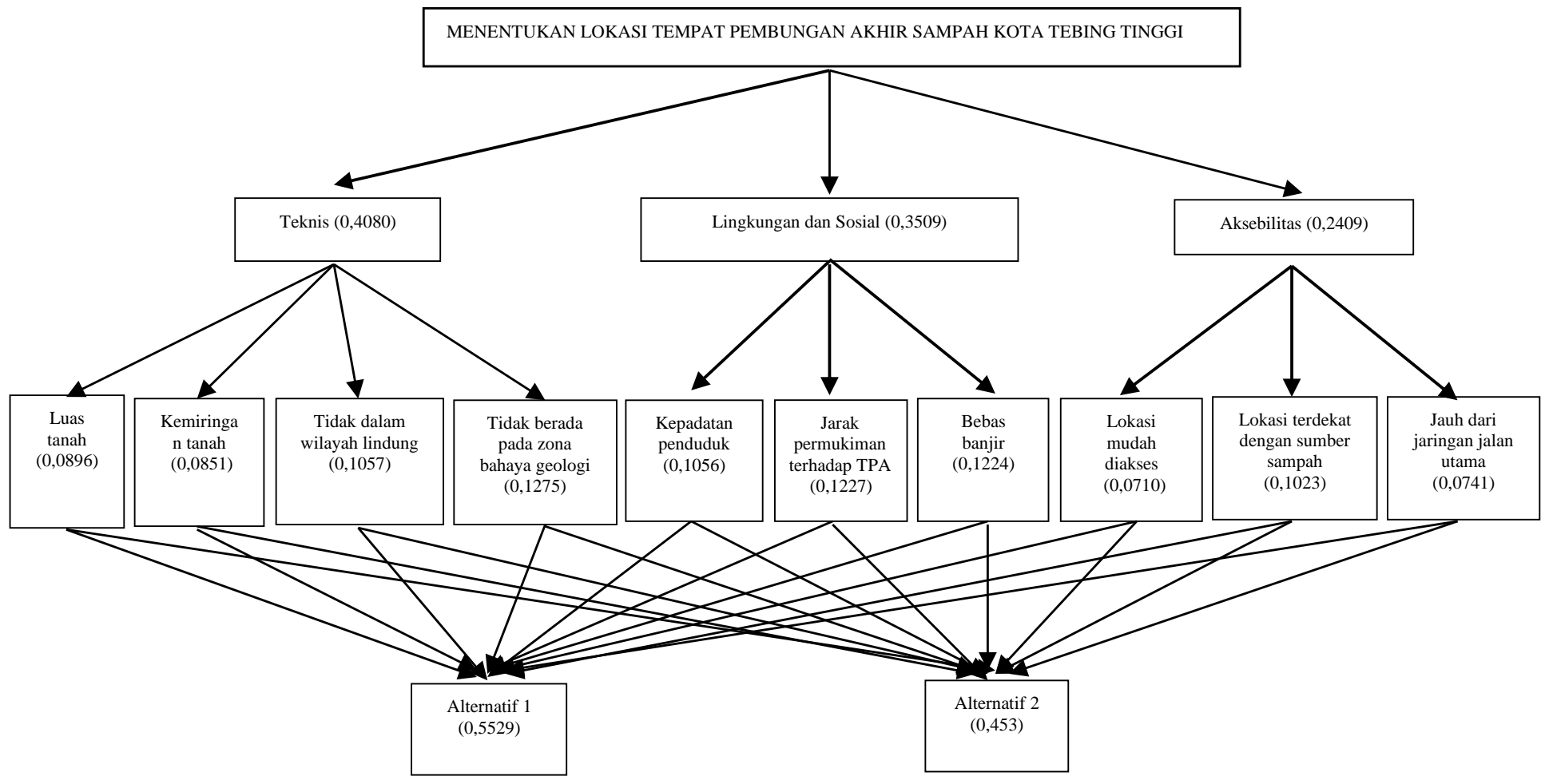

